\title{
The Mediating Effect Of Work Cooperative Attitude On The Affecting Of Organizational Justice To Dysfunctional Behavior And Impacted To The Loan Controller's Performance
}

(Eevidence from the biggest ten of national bank listed in the Indonesia Stock Exchange in Jakarta, 2011) Banking and Organizational

\author{
Dr. Tigor Sitorus
}

University Bunda Mulia Jakarta, Indonesia sitorus tigor@yahoo.com

\begin{abstract}
The objective of this research is to build a theoretical and an empirical model of the Work Cooperative Attitude of Loan Controller on decreasing the Dysfunctional behavior at banking industries and its impact to Loan Controller's Performance. This study wanted to test empirically direct and indirect effects of ; The first, The Organizational Justice to Dysfunctional behavior, The second, The Organizational Justice dysfunctional behavior mediated by Work Cooperative Attitude, the third, The Work Cooperative Attitude to Loan Controller's Performance, The fourth, the Work Cooperative Attitude to Loan Controller's Performance mediated by Dysfunctional behavior at the biggest ten of bank listed in Indonesian stock exchange, Jakarta area in 2011.

The Structural Equation Modeling and Analysis of Path by Amos Software 16.00 used to analysis data which result have a high goodness of fit, and the test of simultaneous and individual test proved significant with coefficient < 0.05 and the variation of the dependent variable could be explained or estimated by the independent variables with coefficient adjusted R Square > 0.60 .

The results of the analysis shows that; The First, Organizational justice is positive but not significantly increasing the Dysfunctional behavior, The second, effort to decrease the dysfunctional behavior will significant and more strength throughout increasing the variable of Work Cooperative attitude. The Third, effort to increase The Loan Controller's Performance will significant by decrease the Dysfunctional behavior and increasing Work Cooperative Attitude simultaneously.

This study recommend about the importance of building Work Cooperative Attitude of loan Controller with dimensions; cooperative work, openness, honesty, commitment, mutual respect. Those could be obtained if the company has a good procedural and distribution justice for loan Controller.
\end{abstract}

Keywords: Equity, Justice, Work Cooperative Attitude, Behavior, Performance, Contingency theory, Learing organization.

\section{Council for Innovative Research}

Peer Review Research Publishing System

Journal: International Journal of Management \& Information Technology

Vol. 8, No. 3

editor@cirworld.com

www.cirworld.com, member.cirworld.com 


\section{INTRODUCTION}

\subsection{The background}

The company objective and goal are to obtain a developing as sustainability throughout mobilized asset and all capabilities such as; property, human resources and information. In business practices, organizations or companies often faced to the reality of asymmetric information. This condition will be affecting in the difficulty the owner, management and employee to achieve company goals as a superior entity. Asymmetric Information is usually used by the certain parties to gain an unfair advantage and the other side will be disadvantaged for an organization.

The case of Asymmetric Information is popular in Indonesian public discussion such as; the case of Century Bank and Global Bank. In both case, there were an indication of "error omission or error commission" which made by manager or by owner. This occurred because the model of supervision and control fixated on quantitative approaches that rely on quantitative data and information only. In a Controlling, the real qualitative approach also plays an important role as part of the dynamics and consequences of human subjects with a unique behavior.

According to Resources based and knowledge theory, Human as a major company's resource is required, and their capability must be improved for generating a certainty for reducing cost in order the company can obtain performance optimally. So to realize superiority and dedicating of human resources need a variety of skills that can support the performance. (Aaker, 1989; Oliver, 1997 in Ferdinand, 2003).

Recently, the researcher's focuses is about employee's reaction like employee's job satisfaction. Job satisfaction is very important for the employee and for the company. Therefore, this area be attracting for academics and corporate practitioners. Job satisfaction is one form of employee behavior, which is defined as something fun or positive side of the emotional outcome assessment work experience person (Locke, in Vanderberg and Lance, 1992).

The Institute of Internal Auditors (IIA) has defined fraud is; an array of regulation and illegal acts characterized by intentional deception. It can be perpetrated for the benefit of or to the detriment of the organization and by persons outside as well as inside organizational. From this definition shows that the existing irregularities and fraud or illegal acts, intentional fraud that benefit individuals and organizations, that behind it there are the injured party, while the culprit could be an organization or individual. It means that this can be done for the benefit and / or losses by people outside the organization or others in the organization. Thus it can be said that this fraud is a false representation or concealment of material facts that caused someone has something illegal.

Before financial crisis occurred, in 2006, The Central Bank of Indonesia has issued a bank Indonesia Regulation No.8/19/PBI/2006, which requires national banks aware to the principle of prudence in disbursing funds. This regulation aims to encourage the banking sector and other financial institutions to grow up their competition ability. Creating a Positive Work Environment is not possible to create culture of honesty, openness and mutual help without creating a positive work environment. Positive work environment is not created automatically, but it must be processed and constructed. Positive open door policy for employees as well as adherence to systems and procedures is a boost for the organization to fight fraud.

Open policy for the prevention of cheating has two ways, first, the fact a lot of people who have commitment to fight fraud, but he did not have anywhere to whom he was pitted and delivered. If he keeps himself he loses the right opportunity to take action and consequently he could do wrong. Second, the open door policy will help managers and others to understand the pressures, problems and reasons employees. Understanding of the managers this is a proactive step to prevent fraud.

In building a Code of Ethics, culture of honesty, openness and mutual helping cannot be created in the absence of a code of conduct and compliance with the code. Some Literature on moral building said if we want the people to be honest, we have to form a habit with these models. The company that successfully to prevent a cheating needs to have a label for it and usually given a code name. The formulation of a code of ethics describes what can be done and that is not good and should not be done. Periodically employee must read and sign a code of conduct not only to push back his understanding of what the meaning is worthy and who is not worthy, but also stressed that it is important for company.

\subsection{Phenomenon Gap}

Phenomenon of organizational justice is the perception of justice aspect of organizational life that related with employee reactions on the fairness and feasibility assessment in organizational life. The concept of organizational justice developed from equity theory (Korsgaard et al., 1995; Cowherd and Levine, 1992; Skarlicki and Folger, 1997; Schminke et al., 1997). Based on equity theory, organizational justice refers to employee perceptions of fairness and balance between the employee's inputs with the results that they received.

For academics and management, the assessment of the employee's desire to move to another organization is the focus of subject and a special concern, so that they understand something that became a driving force of desire to move to other organization and they could be control it. While in the practical perspective, skills and expertise as well as policies that can be applied to suppress the desire among employees to move urgently needed. The ability of the management to control and hold the desire of employee move out, that is implicated to the company's ability to retain employees who have the skills and expertise. It could be save the cost of human resources management practices such as; recruitment, selection, relocation, training and development (Winkler and Janger, 1998). 
The other phenomenon in industry and organization are; professionals tend to be more committed to the profession than the company where they worked. Employees who are committed to the profession do not always refer to an organization, so that employees like this are always moving to another organization (Fineman et al., 2005). The phenomenon is one of them caused by the gap between employees working in one company with employees who work in other company, even though they have the same job description. Some people are affected in the end took the decision to move the work to another company, but not a few who decided to stay working in related companies but there is a risk of dysfunctional behavior like cheating or fraud.

As an intermediation function that collects funds from the public and distributes it back to the public, the bank is vulnerable to fraud. When fraud occurs, the bank becomes impaired, so the bank should be working hard to obtain their goal.

\subsection{Research Gap}

\section{A. Research related to the relationship of Organizational Justice Perceptions with Job Satisfaction}

Moorman et al. (1998), said that the perception of procedural justice has a weak negative impact on the behavior of members of the organization because of the perception of injustice affect the degree of feel confidence of employee for male even female about the organization's values.

Amanuel G.Tekleab, (2004), in the journal of Extending The Chain of Relationships Among Organizational Justice, Social Exchange, And Employee Reactions: The Role Of Contract Violations, looked at the relationship between justice organization with employee reactions. The study found that the quality of a good relationship between the organization and employees provide significantly better reaction from employees.

Asghar, Parvaneh Zeinali Someh, 2009, in The Study of Personnel and Customer Perception of Organizational Justice tried to look at the relationship with job satisfaction organizational justice, and to customer satisfaction, the research says that there is a positive relationship between organizational justice and job satisfaction of personnel.

\section{B. Research related to the relationship between Dysfunctional Behavior with The Performance}

Peterson and Gibson (2003) shows a case in which the procedure ICP (Internal Control Procedures) is weak with respect to the lack of segregation of duties and independence of officers on cash reconciliation as well as deficiencies in the implementation of the documentation, then these factors will affect the quality of control and allows occurrence of dysfunctional behavior like cheating. This study, argued that cheating employees is almost certainly occur in situations where both the motivation to act deviate appear (as a result of the low perceptions on organizational justice), and there are opportunities to commit fraud because of the internal control weak.

In contrast to other researchers who tried to see the many variants of dysfunctional behavior through the management control system research, the finding are not tight budget system, the manipulation of the size of performance (Argyris, 1952; Hopwood , 1972; Onsi , 1973 ; Merchant, 1990; Dunk, 1993; Chow , et.al , 1996), this suggests that the study was not focused on dysfunctional behavior alone. While Marginson and Ogden (2005) research focuses on the relationship between management control systems with a loose budget. From the results of research conducted Marginson and Ogden (2005) suggests that there is a relationship between dysfunctional behavior with control systems that are limited on budget allowances system.

Teerooven Soobaroyen (2006) examined the relationship between Management Control Systems with dysfunctional behaviors that develop and follow research conducted by Jaworski and Young (1992). Soobaroyen (2006) suggests that there is a relationship between Management Control Systems with standard operating procedure , budgetary participation, reliance on accounting performance measures with behavioral dysfunctional in variant manipulation of information and manipulation of performance measures in the selection of actions (dysfunctional behavior gaming).

On the other perspective, Jansen \& Glinow (1985) in Malone and Roberts (1996) suggests that individual behavior is a reflection of the personality whereas situational factors that occurs when it would encourage someone to make a decision to behave. The opinion suggests that the dysfunctional behavior of personnel can be caused by personal characteristics (internal factors) as well as situational factors when performing control activities (external factors).

\subsection{Originality/Strengthen}

This research tried to develop the relationship of organizational justice with loan controller's dysfunctional behavior with variance; cheating, human error, employee destructive tolerant, permissive, apathy, unaware. This research different with Marginson and Ogden (2005) that concern to the relationship of management control system with employee dysfunctional behavior, with variance manipulates of performance that found a negative relationship between management control system with employee dysfunctional behavior.

This research tried to increment variable of Work Cooperative Attitude in the relating of organizational justice with Dysfunctional behavior and Loan Controller's performance that indicated by; cooperative work, openness, honesty, commitment, mutual respect for reducing loan Controller's dysfunctional behavior. This research different with Moorman et.al (1998), He said that a weak perception of procedural justice has a negative impact to the behavior of members of the organization. 


\subsection{Problem Formulation}

According the background, the phenomenon in the banking business and the research gap that has been described above; the authors propose research problems are how the dysfunctional behavior can be decreasing in order to improve the performance of the Loan Controller's Performance.

According this problem, the author make five research questions as bellows:

1) Does The Organizational justice decreases the Dysfunctional behavior

2) Does The Organizational justice increases the Work Cooperative Attitude

3) Does Work Cooperative Attitude decreases the dysfunctional behavior

4) Does the Dysfunctional behavior decreases Loan Controller's Performance

5) Does Work Cooperative Attitude increases Loan Controller's Performance

\subsection{Research Objectives}

Based on the background of problems and research questions, the research aims are;

1) To analyze the effect of Organizational justice to the Dysfunctional behavior

2) To analyze the effect of Organizational justice to the Work Cooperative Attitude

3) To analyze the effect of Work Cooperative Attitude to the dysfunctional behavior

4) To analyze the effect of the Dysfunctional behavior to Loan Controller's Performance

5) To analyze the effect of the Work Cooperative Attitude to Loan Controller's Performance

\subsection{Research Output}

Through this research, may contribute for academics and organizational practitioners in the form of recommendations and the development of theoretical model empirical model about concepts of Organizational Justice and Performance.

a. Academic implications ;

It has implications for academic research by providing support for the development of Equity theory, Achievement theory and the theory of organizations that look from a wider perspective on the influence factors of Loan Controller's Performance ;

1) To suggest how the Loan Controller's Performance could be increased by increasing the Work Cooperative Attitude and Decreasing Dysfunctional behavior.

2) To suggest how the Dysfunctional Behavior could be decreased by increasing Organizational Justice and increasing the Work Cooperative Attitude.

b. Practical Organizational implications;

1) Provide a guidance in improving Loan Controller's Performance, in processing of loans as well as regulation and procedures, therefore the practitioners should be implementing organizational learning to build and develop the human resource behavior and build Loan Condoler's code of conduct, culture of honesty, openness and mutually.

2) Be aware to the importance of knowing Loan Controller track records and relating to the customer when to placement them. The management must be checking document file of controller and integrated data administration and information to market of employee, the process of screening and filtering as well as an integrated analysis of the data and information of the Controller on the last years, and better recruit them from inside.

\subsection{Research Outcomes}

This research provide a propose new model to Indonesian Government as regulator and Indonesian Central Bank as executor in order more prudent and aware in selecting of employee who Controls and Monitor Loan. The Bank must be know who the employee would control a Loan Processing.

\section{LITERATURE AND EMPRICAL RESEARCH REVIEW}

\subsection{Road Map}

In this chapter, the literature described the Agency Theory, Theory of Equity; Resources based Theory, Transactional Cost Theory, Organizational Learning Process Theory, Strategy Map, Locus of Control, the concept of performance, Organizational justice.

From the description of several research and the relationships inter variable, it acquired one basic theoretical propositions and models, then proposed 1(One) model empirical research study of mediating effect of Work Cooperative Attitude on the relating of organizational justice with loan controller's dysfunctional behavior and impacted to Loan Controller's Performance. Work Cooperative Attitude is indicated by; cooperative work, openness, honesty, commitment, mutual respect for reducing loan Controller's dysfunctional behavior.

\subsubsection{Agency Theory}


In a framework of financial management, there is a relationship between shareholder and manager and between shareholder and creditor. The Manager may be making a decision contrary to the company's goal on maximizing shareholder's wealth. The decision to expand the business, driven by the desire of the manager to make every division was developed in order to gain responsibility and greater compensation.

Jensen and Meckling (1976) said that assert agency problem would occur if the proportion ownership's control is not full, that's made the managers more focused on the company's overall risk, such as business risk and financial risk only, not focused to rise up the ownership's wealthy.

Furthermore, Pawlina and Renneboog (2005) described the agency problem occurred because of an asymmetries information between shareholders and managers such as; Adverse selection and Moral Hazard. Adverse selection in the company while the owner have less information about the company and the managers did not share the information as fully to shareholders or to potential shareholders. This condition has a consequence for shareholders do not want to invest or withdraw their money from the company or to purchase shares at in the low rate. The moral hazard occurred when the manager take action without the owner and get the gain for themselves and affect to owner's welfare. In public companies, the separation control between ownership and management, it is difficult for shareholders and creditors to look extent of the performance management.

\subsubsection{Equity Theory}

John Stacey Adams equity theory suggests the motivation to work in 1963. In this theory, implicitly recognizes that there are several variables as factors affecting the assessment of every individual and the perception of their relationship with their job, and ultimately against their employers. Awareness and other features stronger influence than the previous model ie the influence of colleagues and friends, in the form of consciousness, and in this case is, "what is perceived fair and reasonable". As an employee, every person seek a fair balance between what's being input into our job and what should we get from the company. Inputs are typically; effort, loyalty, hard work, commitment, skill, ability, adaptability, flexibility, tolerance ,determination, heart and soul, enthusiasm, confidence, support of colleagues and subordinates, personal sacrifice, employees need a sense of justice that is balance between input and output. Output typically all financial rewards such as; salary, alimony payments, retirement benefits arrangements, incentive and commission, the recognition of intangible such as; recognition, reputation, praise and gratitude, responsibility, stimulation, training and development, promotion.

If employee feel that sufficient and adequate input appreciated by output (the fairness benchmark being subjectively derived from market norms and other references that can be used as a reference) then the employee will be happy at work and more motivated to continue to provide appropriate input to obtain the output, however, if the opposite is true, then the employee should not be motivated.

\subsubsection{Learning Theory}

Organizational learning process meant that the company has expertise in creating, retrieving, and transferring knowledge, and modifying its behaviour to reflect new knowledge and experience. Learning organization refused stability by continuously self-evaluation and experimentation. The concept of individual learning implicitly explains that humans have the ability to learn and change to achieve her maturation. Humans are expected to always be willing to learn about the environment, and at once familiar and then actualize him self. Organizations also learn from other organizations, such as when a company acquires or merges with another company, the company can absorb the methods and procedures of the company or combine them in a way and its own procedures, so that new knowledge is formed both process and personnel. Without organizational learning mechanisms, then the organization will not be able to maintain the consistency of his growth and development, so it is not able to generate greater added value for stakeholder.

Senge (1990:2) argued in a learning organization, employers continue to provide opportunities for every member of the organization to learn because the learning abilities will be increased and organizational learning have a strong orientation on human resources, stating "people Continually expand their capacity to create the results they desire, where new and expansive patterns of thinking are nurtured, where collective aspiration is set free, and where people are Continually learning how to learn together."

Marquardt, (1996:21). Put forward in order to achieve and maintain a competitive advantage in the business environment is changing rapidly, The organization must be able to improve their learning capacity. Group or team learning involves an increase in knowledge, skills and competencies that are united by the group and in the group. While organizational learning refers to the increased intellectual and productive capability gained through the commitment of the entire organization and the opportunity to perform continuous improvement. Marquardt (1996:30) then added a further dimension is important in building a learning organization that is dialogue. To realize the organizational learning process that takes six dimensions namely systems thinking, mental models, personal mastery ,team collaboration, sharing a common vision, and dialogue.

Khandekar and Sharma (2006) used 9 items to measure learning process that related to human activity, namely : human resource strategy, training and learning, performance appraisal, rewards and incentives, favourable conditions, team work, knowledge creation , management quality, and flexibility.

\subsubsection{Locus of Control Theory}


According has been noted above that the internal control are built in an effort to prevent dysfunctional behaviors that can be done by employees or management even though by the owner. The phenomenon of dysfunctional behavior is not enough to just be assessed through accounting knowledge, but also need to involve multiple disciplines, including micro and macro economics, law, social sciences, and psychology. The study that is mention above try to explain the factors influence the effectiveness of internal control, compliance compensation, observance of the rules of accounting, management information asymmetry and morality against unethical behavior and trend of accounting fraud. Furthermore, this study also aims to examine the effect of unethical behavior against the trend of financial fraud.

According to Jansen \& Glinow (1985), an individual's behavior is a reflection of the personality whereas situational factors that occur when it would encourage someone to make a decision. Of that argument, it can be concluded that the personnel dysfunctional behavior can be caused by personal characteristics (internal factors) as well as situational factors when performing the activity of control (external factors).

Locus of Control plays a role in motivation, locus of control may reflect different different motivations and different performance. Internal Locus of Control will tend to be more successful in the career of the external locus of control, they tend to have higher levels of employment, promotion faster and earn more money. In addition, internal locus of control have a higher satisfaction with their work and look better able to withstand stress than external locus of control (Baron \& Greenberg , 1990 in Praise, 2005).

Locus of control affects the acceptance of dysfunctional behavior controller or actual employee dysfunctional behavior such as job satisfaction, organizational commitment and turnover intention ( Reed et al ; 1994 in Praise , 2005; Donelly et al,2003).

\subsubsection{Dysfunctional behavior}

Jaworski (1988) and Mac Innis (1989) recognizing four activities includes dysfunctional behaviors, that are; gaming , smoothing, focusing, and reporting invalid, while Ramaswami (1996:106) defined the dysfunctional behavior as follows; Dysfunctional behaviors pertain to employee activities that further the personal interests but Harmful to long term organizational performance.

Peterson , BK , (2004) ; Wolfe , DT \& Hermanson, DR , (2004) explain the cause of the fraud, the Fraud Triangle theories or models described three factors that together lead to cheating like; 1) motive or pressure, 2) perceived opportunity, and 3) rationalization of fraud perpetrators or the ability to seek justification on. Motive or pressure can be urgent financial need or a desire for revenge addressed to the company's activity. Perceived opportunity or the opportunity to commit fraud is generally associated with factors inherent the organization. A weak internal controls or work culture too trusting someone is an example of the opportunities. Nevertheless, in the case of fraud on the bank, the opportunity to cheat can also be caused by factors outside the bank, for example; a weak oversight of banks, the lack of law enforcement, or the absence of regulation that limited the space that allows the fraud. Rationalization is the ability of a person to justify their actions.

According the various explanations and literature review that has been described above, it could be proposed a proposition as follow;

Proposition : Work Cooperative Attitude is A work attitude of Loan Controller, indicated by cooperative work, openness, honesty, commitment, mutual respect. This Attitude potentially decreases the dysfunctional behavior and increases the performance of the Loan Controller.

\section{RESEARCH METHODS}

\subsection{Research Design}

The design of this study used survey methods. This research is an approach to Management and organization, especially with the main study banking and finance, management control systems and strategic management. In particular, using transaction cost economics theory, contingency theory and agency theory regarding the external business environment uncertainties and other variables, namely strategic planning, internal control systems and the performance.

\subsection{Population and Research Sample}

\section{a. Population}

The population in this study is all level of manager who involved directly in loan processing in ten Indonesian banks that operating in Jakarta area, where the national bank listed on the Jakarta Stock Exchange Indonesia until 2011. As reasoning in choosing the listed bank, because the listed bank has been through eligibility mechanisms such as; audited by external auditors, and other consultant.

\section{b. Sample}

Before withdrawal the sample, at the first time the author set a withdrawal method sample. The sample method is the purposive sample method (Ferdinand Augusty,2006). As Reasoning for choosing purposive sampling method is to consider all information related to the research problem can be extracted from the respondents who were directly involved in the loan approval process. Therefore, samples in this study are the head of Loan Controller at the top ten Indonesian banks which listed on the Stock Exchange until 2011 . Every bank represented by 12 branches in Jakarta. As Reasoning for choosing Loan Controller, because they understand, dominate and involved in the loan approval process. As Reasoning for choosing the Jakarta branches area because the commercial banks in the Jakarta area, contributed the largest NPL at Rp. 22.2 trillion (45\%) of the total NPLs throughout Indonesia at Rp. 49.3 trillion (BI statistics Vol. 9 No.3, 2011). Every branch represented by 1(one) Loan Controller, so all sample are $10 \times 12$ 
= 120 Loan Controller from 120 offices. According to the term, the minimum sample is 10 until 25 multiply from the amount of independent variables, where the amount of independent variables is 2(two) variables. (Roscoe in Sekaran, 2003, Hair et al, in Ferdinand Augusty,2006, Tabachnic and Fidel,2006).

\subsection{Operational of Variables}

Basically the necessary data in this study can be grouped into 3 (three) groups of variables, namely: Independent Variable, Dependent Variable, Variable Intervening, are;

1) The first variable $(\mathrm{PKO})$ is the Organizational Justice perception. This variable is independent variable, with latent variables are; equality, index credit point or balancing of input-output, role adapting, positive communicating.

2) The second variable (COP) is the Work Cooperative Attitude. This variable is mediating variable with latent variable are; cooperative work, openness, honesty, commitment, mutual respect.

3) The third variable is Dysfunctional Behavior (DF). This variable is intervening variable with latent variable are; Cheating, Fault Work, Employee destructive tolerant, permissive, apathy, unaware behavior. This variable affecting Credit Performance.

4) The fourth variable (KP) is the Loan Controller's Performance. This variable is the dependent variable with latent variable are; quality of account reviewing, strictly to time.

So that the model can be made mathematically as follows:

$$
\begin{aligned}
& D F=f(P K O)+e \\
& D F=f(P K O)+f(C O P)+e \\
& K P=f(C O P)+e \\
& K P=f(P K O)+f(C O P)+f(D F)+e
\end{aligned}
$$

\subsection{Measurement of Scale}

The measurements will be used in this study is the measurement interval data with Likert scale (Likert, 1963). This results in a measurement scale that allows the calculation of average, standard deviation, statistical parameters, correlation and so forth. (Summated rating methods, C. Bird, 1988), and developed by Tsui, Anne S. Lyman W. Porter (1997) in measuring the effect of investment in manpower to employee performance, with scoring from agree to strongly agree (score of 1 to 7 ), and by Heneman, HG (1974) in the journal Comparison of self rating of superior managerial performance, as well as by Baldauf and Cravens in the journal The effect of moderators on the salesperson behavior performance and salesperson outcome performance and sales organization effectiveness relationship (2001), measurement using a scale of Likert where "7" points, and data analysis techniques using Multiple Regression analysis techniques.

\subsection{Data Collection Techniques}

The data required in this study consisted of primary data and secondary data. Primary data required in this study was collected by conducting field research that is, directly to the banks which listed on the Stock Exchange. Secondary data was collected through library research.

\section{1). Field Research}

Primary data required in this study relates to the identity of the bank which is the first group. The second group of data used to measure variables control environment, information systems, control activities as well as bank loan performance variables. To obtain primary data, the author used field research with the following data collection techniques: Questionnaire, Observation, and Interview.

\section{2). Library Research}

Library research is needed to collect the data for the secondary support as well, complement, and collect primary data. Secondary data collection technique is to learn from the journals, reports from relevant agencies as well as other writing that had to do with this research such as; the financial statements of the banks listed on the Stock Exchange in 2005-2011 in Indonesia Stock Exchange which issued in the Indonesian Capital Market Directory books.

\subsection{Method of Analysis}

In this study, the author used a technique of analysis by the method of Structural Equation Modeling (SEM). SEM is a method of analysis in addition to providing information about the simultaneous causal relationship between the variables. It provides information about the load factors and measurement of errors. SEM is able to analyze the relationship between latent variables with indicator variables, the relationship between latent variables with another, as well as knowing the size of the measurement error. (Ghozali,2005). To support Structural Equation Modeling, in this study the author used the software of Amos 21:00.

\section{FINDING AND DISCUSSION}

\subsection{Finding}

\subsubsection{Testing Model}


The SEM assumptions that must be met are as follows:

\section{Sample Size}

Sample size that must be met in the modeling of SEM is the minimum amount to 100 (, and then use the comparison of 5 observations for each parameter to be estimated. Therefore, when developing a model with 20 parameters used then minimum 100 samples. In this study, the number of samples selected 120 people, so that the number of eligible sample (Hair et al, Tabachnic \& Fidel in Ferdinand Augusty,2006).

\section{Normality and Linearity}

Distribution of data must be analyzed to see if the assumptions of normality are met so that data can be processed further with SEM modeling. Normality can be tested with keep an image histogram can be tested with the data or statistical models. Normality test is done by using the skewness test that showed almost all normal variables at the 0.01 level (1\%). This is reflected in the value of skewness CR under \pm 2.58 (Arbuckle, 1997:78). Multivariate value in testing multivariate normality is kurtosis coefficient, if the results are still below the limit of \pm 2.58 ; this means that there is data used multivariate normal distribution.

\section{Extreme numbers (Outliers)}

Outliers are observations that appear extreme values both univariate and multivariate namely that arise due to the combination of its unique characteristics and look very much different from the other observations. This model proved that no outlier or no extreme value.

\section{Multicollinearity}

Multicollinearity is a condition of a high correlation between some or all of the independent variables in a multiple regression (Cooper and Emory, 1996:324). Multicolinearity can be detected from the determinant of the covariance matrix. Covariance matrix determinant value is very small gives an indication of multicolinearity problem. In Table visible correlation between the independent variable value is less than $1(r<1)$, meaning the independent variable no symptoms of multicolinearity.

Furthermore, the following assumptions are met then conducted a feasibility SEM models. To test the feasibility of the developed model in this structural equation model, it will be used some eligibility index models. According to Arbuckle (1997:85) AMOS is also used to identify the proposed model meets the criteria of a good structural equation models.

The criteria are;

\section{1) Degrees of freedom (Degree of Freedom) must be positive}

Output results, degree of freedom are 10 , which mean that the model is being developed to meet the criteria as a good model.

\section{2) X2 (chi square statistic) and probability}

Fundamental test equipment to measure the overall fit is the likelihood ratio chi-square statistic. Significant level of acceptance is recommended if $p \geq 0.05$ (Hair et al., 1998:389), which means the actual input matrix with the predicted input matrices were not statistically different. $\mathrm{R}$ degree of freedom. Amos output results showed that the ratio of chi square of 90.12 or less than $5 \times 197=985$ (Wheaton, 1977).

Besides ratio chi-square, according to Hair et al. (1998:340) recommended value of conformity to accept a model is the value of CMIN / DF is less than or equal to 2.0 or 3.0. While the value of CMIN / DF $=0.924$ or $<2.0$ meaning this model well and can be used.

\section{3) Goodness of fit index (GFI)}

GFI is used to calculate the weighted proportion of the variance in the sample covariance matrix is described by the covariance matrix can estimated population. 16:00 Amos output results demonstrate GFI coefficient of 0.95 or $95 \%$. This index reflects the overall suitability of the model is calculated from the residual quadratic model that predicted compared with the actual data. Goodness of Fit Index value is usually from 0 to 1 . The larger the sample size the study the greater the value of GFI. Better value close to 1 indicates that the tested models have good agreement (Hair et al., 1998:387) is said to be good value GFI $\geq 0.90$.

\section{4) Adjusted GFI (AGFI)}

GFI AGFI states is an analogue of R2 (R square) in a multiple regression. Fit Index can adjust the degree of freedom available to test whether the model is accepted estimated. 16:00 Amos output results show AGFI coefficient of 0.915 or $91,5 \%$. Acceptance rate is recommended if a value equal to or greater than 0.9 has.

\section{5) Tucker-Lewis Index (TLI)}

TLI is an alternative incremental fit index that compares a model was tested against a baseline models. The Amos output results show TLI coefficient of 1.00 or $100 \%$. Acceptance rate is recommended if a value equal to or greater than 0.9 has. Recommended as a reference value for the receipt of a model is greater than or equal to 0.9 and a value close to 1 indicates a very good fit. TLI is a fit index is less affected by sample size. 


\section{6) CFI (Comparative Fit Index)}

CFI is also known as the Bentler Comparative Index. CFI is an incremental suitability indices are also compared with the null model tested and estimated models. Amos output results show the CFI coefficient of 0.98 or $98 \%$. It was said to be a good index to measure the suitability of a model because it is not affected by sample size (Hair et al., 1998:289). Index indicating suitability models tested had a good is if the CFI $\geq 0.90$.

\section{7) RMSEA (Root Mean Square Error of Approximation)}

RMSEA values indicate the goodness of fit is expected when the model is estimated in the population. Amos output results show RMSEA index of 0.00 or $0 \%$. RMSEA value is less than or equal to $0.08(8 \%)$ is an index to the acceptability of the model showed a close fit of the model was based on degree of freedom. RMSEA is an index of measurement that is not influenced by the size of the sample so that the index is usually used to measure the fit model on large sample numbers.

The indices are used to test the feasibility of a model can be summarized in the table below.

Table - 4.1: Goodness of Fit Full Model of the relating between Organizational Justice with Work Cooperative Attitude and Dysfunctional Behavior, impacted to Loan Controller's Performance.

\begin{tabular}{|l|l|l|l|}
\hline Goodness of Fit Index & Cut off Value & Analysis Results & Evaluation \\
\hline X2 Chi square & $<985$ & 36,037 & Good \\
\hline Significance Probability & $\geq 0,05$ & 0,606 & Good \\
\hline GFI & $\geq 0,90$ & 0,950 & Good \\
\hline AGFI & $\geq 0,90$ & 0,915 & Good \\
\hline CMIN/DF & $\leq 2,00$ & 0,924 & Good \\
\hline TLI & $\geq 0,90$ & 1,00 & Good \\
\hline CFI & $\geq 0,90$ & 0,98 & Good \\
\hline $\begin{array}{l}\text { RMSEA } \\
\text { Hoelter } 0.05\end{array}$ & $\leq 0,08$ & 0,00 & $\begin{array}{l}\text { Good } \\
\text { Good } \\
\text { Hoelter } 0.10\end{array}$ \\
\hline
\end{tabular}

Source: Results Output Full Amos 16:00

\subsubsection{Data}

Chart - 5.1: Model of the Relating between Organizational Justice with Work Cooperative Attitude and Dysfunctional Behavior, impacted to Loan Controller's Performance.

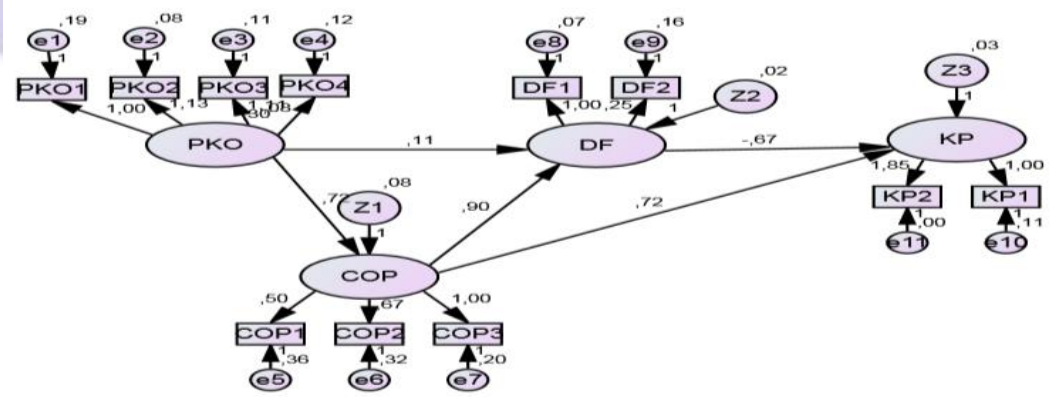

FIT MODEL TESTED :

$X 2$ Chi square $=36.037 ;$ Significance Probability $=0.606 ; \mathrm{GFI}=0.950 ; \mathrm{AGFI}=0.915 ; \mathrm{CMIN} / \mathrm{DF}=0.924 ; \mathrm{TLI}=1.00$; $\mathrm{CFI}=0.98 ; \mathrm{RMSEA}=0.000$; Hoelter $=207$.

Source : Amos 16.00 Output

Table 5.1. : The Affecting Model of Organizational Justice to Work Cooperative Attitude and Dysfunctional Behavior, impacted to Controller's Performance. 
Regression Weights: (Group number 1 - Default model)

\begin{tabular}{|c|c|c|c|c|c|c|c|}
\hline & & & Estimate & S.E. & C.R. & P.sig & Label \\
\hline COP & $<---$ & PKO & ,718 & ,106 & ,802 & $\star \star \star$ & \\
\hline DF & $<---$ & COP & ,903 & ,333 & ,710 & ,705 & \\
\hline DF & $<---$ & PKO & ,108 & ,241 & ,446 & ,655 & \\
\hline $\mathrm{KP}$ & $<---$ & DF &,- 672 & ,775 &,- 379 & ,007 & \\
\hline $\mathrm{KP}$ & $<---$ & $\mathrm{COP}$ & ,720 & ,861 & ,387 & ,009 & \\
\hline PKO1 & $<---$ & $\mathrm{PKO}$ & 1,000 & & & & \\
\hline PKO2 & $<---$ & PKO & 1,125 & ,104 & 10,825 & $* * *$ & \\
\hline PKO3 & $<---$ & $\mathrm{PKO}$ & 1,106 & ,105 & 10,563 & $* \star *$ & \\
\hline PKO4 & $<---$ & PKO & ,083 & ,060 & 1,382 & ,167 & \\
\hline KP1 & $<---$ & $\mathrm{KP}$ & 1,000 & & & & \\
\hline KP2 & $<---$ & $\mathrm{KP}$ & 1,849 & 1,578 & 1,172 & ,241 & \\
\hline COP3 & $<---$ & $\mathrm{COP}$ & 1,000 & & & & \\
\hline COP2 & $<---$ & COP & ,668 & ,133 & 5,028 & $* * *$ & \\
\hline COP1 & $<---$ & $\mathrm{COP}$ &, 505 & ,131 & 3,860 & $* * *$ & \\
\hline DF1 & $<---$ & DF & 1,000 & & & & \\
\hline DF2 & $<---$ & DF & 246 & ,081 & 3,046 & ,002 & \\
\hline
\end{tabular}

Source : Amos 16.00 Output

\subsection{DISCUSSION}

\section{a). The Affecting of Organizational Justice to Dysfunctional behavior ( $\mathrm{H} 1)$}

\section{$(\mathrm{PKO} \rightarrow \mathrm{DF})$}

The results of statistical testing shows that coefficient of the affecting of organizational justice to Dysfunctional behavior is 0.108 with significance level at $0.655>0.05$. It means that the direct effect of Organizational justice to Dysfunctional behavior is 10.8 percent but not significant. These tests proved that theoretically, the relating between Organizational justices with Dysfunctional behavior are negative; while empirically prove positive but not significant.

This study results support to the theory of psychological contracts and research results of Morrison \& Rousseau, (1995), Robinson (1997) who argued that the high quality of social exchange in a relationship between the employee with the organization will reduce the likelihood employee's resistance, and will see a breach of the psychological contract, although the explanation for prediction this varies to some degree. The strong relationship exchange between employees with organization, it will tend to be perceived by the employee or the employee will likely see a low gap between employees with the organization.

The results of this study different with Moorman et al. (1998) which says that a weak perception of procedural justice have a negative impact on the behavior of members of the organization because of the perception of injustice affect the degree of confidence in both male and female employees to the organization's values, such as awards to employees who perform and qualified or otherwise impose sanctions the employee is at fault.

The results of this study also support to Cappelli,1999; Erlich,1994; Rousseau,1995; Tsui, Pearce, Porter, \& Hite , 1995) and previous empirical research (Cropanzano, Prehar \& Chen, 2002; Masterson , Lewis , Goldman , \& Taylor, 2000; Rupp \& Cropanzano,2002) that provided evidence that the level of organizational justice is present in management decisions about the quality of the social exchange relationship between individuals and the organizations that employ them, and between employees and the organization as the manager directly. Results of repeated social exchange relationships has proven to be a predictor and indicates a number of employees concerned with attitudes and behavior, including job satisfaction, organizational commitment, citizenship behavior, intention to leave.

b). The affecting of Organizational jutice to Work Cooperative Attitude (H2)

$($ PKO $\rightarrow$ COP) 
The result of this statistical testing shows that the coefficient of the influencing Organizational Justice to Work Cooperative Attitude is 0.718 with significance level $0.00<0.05$. It means that the direct effect of to Work Cooperative is 71.8 percent and significant.

This study supports the opinion of Morrison and Robinson (1997) suggested that the low quality of the exchange relationship with the organization's employees, it will directly affect the level of trust between employees and the organization / employer. Furthermore, a lack of trust employees will contribute to the level of attention to the organization's employees, and as a result, employees will feel the difference between the results of which should be accepted as a duty, a breach of the psychological contract occurs when an employee feel that the organization has failed to fulfill its obligations to the employees .

This study also support to Bakhshi Arti (2009), who explored the relationship between perceived organizational justice, job satisfaction and organization commitment using a field sample. Sample for the present study consisted of 128 employees working in medical college. Regression analysis of the data obtained indicated that distributive justice was significantly related to job satisfaction whereas procedural justice was not found to be related significantly with job satisfaction.

\section{c). The affecting of Work Cooperative Attitude to Dysfunctional behavior (H3) $(C O P \rightarrow D F)$}

Results of statistical tests shows coefficient influence of Work Cooperative Attitude to behavior Dysfunctional is 0.903 with significance level $0.705>0.05$. It means that the direct effect of Cooperative Work Attitude to Dysfunctional behavior is 90.3 percent but not significant. These tests proves that theoretically, the Cooperative Work Relating between Attitudes with Dysfunctional behavior is negative, while empirically proves relating mean positive but not significant.

The results of this study support to Jewel and Siegell (1998) in their research that suggested that attitudes toward a behavior characteristic of a job or feeling, either positive or negative toward an activity that is reflected in feelings of pleasure, accepts or agrees that the results of the activities carried out will have the satisfaction score high. The fact shows that there is still a low cooperative attitude of employees in the company or organization. It can be seen from concrete examples such as some of employees who work only in order to wait for payday, working on what would be done in moderation and lose motivation to pursue a career; it does give an indication of lack of Locus of Control.

The testing in this study also supports Rotter (1990) in (Hyatt \& Prawitt, 2001) states that the locus of internal and external control is the degree to which an individual expects that reinforcement or the results of their behavior depending on their own behavior or their personal characteristics. Those who believe they can control the destination is said to have an internal locus of control, while looking at their lives are controlled by outside forces are said to have an external locus of control is low (Robbins , 1996), which affect the quality of the management control.

This test proves support for Hackman and Lawler in Wijono (2002), which describe the characteristics of jobs that are attached directly to the nature of work characteristics and behavior. The research was carried out in a telecommunications company organization that focuses on five aspects of job characteristics, i.e. skill variety, task clarity, job interests, autonomy, and feedback or feedback. Characteristics of the work are not merely a means to meet the physical needs of employees. Therefore the properties or elements that exist in a job should be rich with dimensions that can support the development of employees and cooperative attitude towards corporate responsibility that will affect the quality of internal control.

This study also support to Manuel G. Tekleab (2000), in the journal Extending The Chain Of Relationships Among Organizational Justice, Social Exchange, And Employee Reactions: The Role Of Contract Violations, look at the relationship between justice organization with employee reactions. The study found that the quality of a good relationship between the employee organization with significant give good reactions from employees.

\section{d). The affecting of Work Cooperative Attitude to Loan Controller's Performance (H4) $(\mathrm{COP} \rightarrow \mathrm{KP})$}

A statistical test result shows the coefficient influence of Work Cooperative Attitude to Loan Performance Controller's is 0.720 with significance level $0.009<0.05$. It means that the direct effect of Work Cooperative Attitude to Loan Performance Controller's is 72 percent and significant. This test proves that theoretically, the Relating between Work Cooperative Attitudes with Controller's Loan Performance is positive and empirically proves relating positive and significant.

This study supports the results of Robbins ( 2001) states that although an individual may be willing and able to do a job but there may be barriers that prevent them from performing, in the form of opportunity. Opportunity in question is an opportunity for personal development, opportunities for career, education and training opportunities. Including factors that affect the performance of employees is the attitude to develop them and take a chance by employees.

Test statistics in this study supports the theory of achievement by Mc.Clelland, to achieve the performance as expected, needed the motivation of the employee concerned. Motivation of the employees in question was motivated by the need as expressed by Mc. Clelland, the need for power, would need achievement and need for 
affiliation. In the third requirement under this study has determined a number of indicators to assess a marketing employee at government's banks and private's banks, such as ; the quantity of work, quality of work, working time , and cooperation (As'sad,2001, Mondy, et.al,1993, Johnson in Dwijanto,2002, and Furtwengler in Ravianto (2002), considered to be highly relevant to marketing employee characteristics (Accounts Officer) government banks and private banks in the achievement of the performance as expected, meaning that the real conditions that exist in the marketing employees very relevant to the needs of all three

This study also support to Locke (2003), who said that job satisfaction as feeling happy or positive emotional state of the job or on the job experience. In line with the Locke (2003) who stated that job satisfaction is a person's attitude or feeling towards the work itself that impact the organization's system of internal control.

\section{e). The Affecting of Dysfunctional behavior to Loan Controller's Performance (H5) $(\mathrm{DF} \rightarrow \mathrm{KP})$.}

The results of statistical testing shows the coefficient influence of Dysfunctional behavior to Controller's Loan Performance is -0.672 with significance level of $0.007<0.05$. It means that the direct effect of Dysfunctional behavior to Loan Controller's Performance equal 67.2 percent is negative and significant. These tests prove that theoretically, the relating between Dysfunctional behaviors with Loan Controller's Performance is negative.

This study support to Parasuraman (1990) that argued the quality of service perceived by the customer can be defined as how much of the gap (gap) between the customer's perception of reality services received (customer perceptions) with expectations (expected service). So the quality of service can be determined by comparing the customer's perception of the real services that have been received by the service expected. Generally speaking, the quality of a good or satisfactory service if the customer perception of service quality perceived (customer perceptions) equal or exceed what the expectations / desired.

This study also support to Ciptono (2005) who argued in his research that marketing employees as the spearhead of the company that interacts directly with the customer, the employee also needs to be satisfied. In other words, total customer satisfaction must be supported by total quality reward linking performance appraisal and compensation systems with the contribution of every employee in improving the quality and increasing customer satisfaction.

This study also support to Journal of Applied Psychology Copyright 2008 by the American Psychological Association, 2008, Vol. 93, No. 5, 945-958. The findings demonstrated that team members' collective emotions and emotional processing represent key mechanisms in determining how dysfunctional team behavior is associated with team performance. The present study examines the association between dysfunctional team behavior and team performance. Data included measures of teams' dysfunctional behavior and negative affective tone as well as supervisors' ratings of teams' (nonverbal) negative emotional expressivity and performance.

\section{CONCLUSION}

1) Organizational justice affect to Dysfunctional behavior is 0.108 with significance level $0.655>0.05$. It means that the direct effect of Organizational justice to Dysfunctional behavior is 10.8 percent but not significant. These tests prove that although theoretically, the relating between Organizational justices with Dysfunctional behavior is negative, while empirically prove relating positive but not significant.

2) Organizational justice affect to Work Cooperative Attitude is 0.718 with significance level $0.00<0.05$. It means that the direct effect of to Work Cooperative is 71.8 percent and significant. These tests prove that theoretically, the relating between Organizational justices to Work Cooperative Attitude is positive, and empirically proved it.

3) Work Cooperative Attitude affect to Dysfunctional behavior is 0.903 with significance level $0.705>0.05$. It means that the direct effect of Work Cooperative Attitude to Dysfunctional behavior is 90.3 percent but not significant. These tests prove that theoretically, the relating between Work Cooperative Attitude with Dysfunctional behavior is negative, mean while empirically prove relating positive but not significant.

4) Work Cooperative Attitude to Loan Controller's Performance is 0.720 with significance level $0.009<0.05$. It means that the direct effect of Work Cooperative Attitude to Loan Controller's Performance is 72 percent and significant. These tests prove that theoretically, the relating between Work Cooperative Attitude with Loan Controller's Performance is positive and empirically prove relating positive and significant.

5) Dysfunctional behavior affecting to Loan Controller's Performance is -0.672 with significance level $0.007<0.05$. It means that the direct effect of Work Cooperative Attitude to Loan Controller's Performance is negative 67.2 percent and significant. These tests prove that theoretically, the relating between Dysfunctional behaviors with Loan Controller's Performance is negative and empirically prove relating negative and significant.

6) Mediating effect of Work Cooperative Attitude on the relating between Organizational justice with Loan Controller's Performance is $0.718 \times 0.720=0.517$ or 51.7 percent, while mediating effect of Dysfunctional behaviors on the relating between Organizational justice with Loan Controller's Performance is $0.108 \times-0.672=-$ 0.072 or negative 7.2 percent. These tests prove that theoretically, if there is a Dysfunctional behavior, so the affecting of Organizational justice to Loan Controller's Performance is negative, but if there is Work Cooperative Attitude on the relating between Organizational justice with Loan Controller's Performance is positive and stronger. 


\section{IMPLICATIONS}

\section{Academic implications;}

It has implications for academic research by providing support for the development of Equity theory, Achievement theory and the theory of organizations that look from a wider perspective on the influence factors of Loan Controller's Performance ;

a) To suggest how the Loan Controller's Performance could be increased by increasing the Work Cooperative Attitude and Decreasing Dysfunctional behavior.

b) To suggest how the Dysfunctional Behavior could be decreased by increasing Organizational Justice and increasing the Work Cooperative Attitude

2. Practical Organizational implications;

a) Provide guidance in improving Loan Controller's Performance, in processing of loans as well as regulation and procedures, therefore the practitioners should be implementing organizational learning to build and develop the human resource behavior and build Loan Controller's code of conduct, culture of honesty, openness and mutually to provide a Work Cooperative Attitudes.

b) Be aware to the importance of knowing your Loan Controller track records and relating to the customer when to placement them. The Management must be checking document file of controller and integrated data administration and information to market of employee, the process of screening and filtering as well as an integrated analysis of the data and information of the Controller on the last years, and better recruit them from inside.

\section{LIMITATION OF RESEARCH AND FUTURE RESEARCH}

\section{a. Limitation}

Some testing and conclusion of this research still has some limitations such as;

1) Object of this study are the biggest ten of national bank only that listed in the Indonesia Stock Exchange. Object of this study have a relative same characteristics of adequate Control System, so that the answer of question describes the indicator of Loan control is relative same and relative high deviation.

2) To collect data and information about loan, more difficult because it is limited by bank secrecy laws, need bureaucracy and head office's manager approval, so that the author could not obtain the documents, data and information about the loan from the branch as quickly, while making an interview can't be done freely because the respondent very careful to answer the question.

\section{b. Future Research Agenda}

1) In the future research, it is suggested that macro variables such as; regulations and laws, business environment may be including in the next research model in order the next research becomes more varied.

2) In the future research, it is suggested that the object of research at the bank which listed on the Indonesia Stock Exchange, Jakarta is not limited to the ten biggest banks, but also developed in the middle and lower banks, so that the respondent relatively more distributed.

\section{REFERENCES}

[1] Adams, J. Stacey 1965. Inequity in social exchange. In Advances in Experimental Social Psychology, Vol. 2, ed. L. Berkowitz. New York, NY: Academic Press.

[2] Anthony, R N and Govindarajan, V., 1995. Management Control Systems. 8th. Chicago: Richard D. Irwin, Inck

[3] Argyris, C. and Schön, D. (1996) Organisational learning II: Theory, method and practice, Reading, Mass: Addison Wesley.

[4] Artur Baldauf, David W. Cravens, Nigel F. Piercy, Sales Management Control Research - Synthesis and an Agenda for Future Research, V25 \#1, Winter, 2005, 7-26.

[5] Cravens, David W, Kent Grant, Thomas N Ingram, and Raymond W La Forge (1992), "In Search of Excellent Sales Organizations", European Journal of Marketing 26 (1):6-23.

[6] Cropanzano, Russell, Cynthia A. Prehar, and Peter Y. Chen (2002), "using Social ExchangeTheory to Distinguish Procedural From Interactional Justice", Group \& Organization Management 27 (3, September):324-351.

[7] Ferdinand, Augusty (2003), Strategic Selling-In Management: Sebuah Pendekatan Pemodelan Strategi Seri Pustaka Kunci. Vol. 3, Research Paper Series. Semarang: BP UNDIP.

[8] Garvin, D. A. (2000) Learning in Action. A guide to putting the learning organization to work, Boston, Mass. Harvard Business School Press.

[9] Ghozali, Imam (2005), Aplikasi Analisis Multivariate dengan Program SPSS. 3rd ed. Semarang: Badan Penerbit Universitas Diponegoro.

[10] Ghozali, Imam (2005), Model Persamaan Struktural: Konsep dan Aplikasi dengan Program AMOS Ver. 5.0. 2nd ed. Semarang: BP Undip

[11] Gibson, James L, John M. Ivan Cevich, and James H Donnelly Jr. (1973), Organizations: Structure, Processes, Behavior. Dallas, Texas: Business Publications, Inc. 
[12] G. Tekleab A and Takeuchi Riki (2004), Extending the Chain of Relationship among Organizational Justice, Social Exchange, Employee Reaction, Maryland University

[13] Hermanson, D. R., Moran, B., Rossie, C. S., \& Wolfe, D. T. (2006). Continuous Monitoring of Transactions to Reduce Fraud, Misuse and Errors. Journal of Forensic Accounting VII, 1730

[14] Howel, G. William (2002), Journal of Policy Analysis and Management. 21(2): 191-218

[15] Hopwood, William S., et al. 2008. Forensic Accounting. By The McGraw-Hill Companies, Inc., 1221 Avenue of the Americas, New York, NY,10020

[16] Hyatt and Prawitt (2001), Does Congruence between Audit Structure and Auditors Locus of Control Affect Job Performance. The Accounting Review, 76

[17] Jansen and Glinow (1985), Ethical Ambivalence and Organizational Reward System, Management Review Vol 10 No. 4

[18] Jaworski, Bernard J, and Deborah J. Mac Innis (1989), "Marketing Jobs and Management Controls: Toward a Framework", Journal of Marketing Research XXVI (November):406-419.

[19] Jensen, W.H. Meckling (1976), Theory of Firm: Theory of firm Managerial Behavior, Agency Cost and Ownership Structure

[20] John Burch dan Gary Grudnitski, Informations Systems Theory andPractice, John wiley And Sons, 1986

[21] Khandekar, A., \& Sharma, A. (2005). Managing human resource capabilities for sustainable competitive advantage: An empirical analysis from Indian global organization. Education \& Training, 628-639

[22] Marquardt, M. J. (1996) Building the Learning Organization, New York: McGraw-Hill.

[23] Malone, C.F., and R.W. Roberts. (1996) Factors associated with the incidence of reduced audit quality behaviors. Auditing: A Journal of Practice \& Theory 15 (2): 49-64.

[24] Mink, O. G., Owen, K. Q. and Mink, B. P. (1993) Developing High Performance People: The Art of Coaching. Reading, MA: Addison-Wesley Publishing Co

[25] Moorman, C., G. Zaltman, \& R. Deshpande (1992) "Relationships between Providers and Users of Marketing Research: The Dynamics of Trust within and Between Organizations," Journal of Marketing Research, 29(August): 314-28.

[26] Njanike Kosmas, Dube and Mashanyanye (2009), The effectiveness of Forensic Auditing in Detecting, Investigating and Preventing Bank Fraud, Journal of The Sustainable Development of Africa, Vol. 10 no. 4, Pennsylvania, Clarion

[27] Parasuraman, Berry, A.L.L. and Zeithmal, V.A. (1991), Refinement and Reassessment the SERVQUAL and Scale. Journal of Retailing, 67: 420-450

[28] Pawlina, G., and L. Renneboog, 2005, "Is investment-cash flow sensitivity caused by agency costs or asymmetric information? Evidence from the UK", European Financial Management 11, 483-513

[29] Ramaswami, Sridhar N (1996), "Marketing Controls and Dysfunctional Employee Behaviors: $A$ Test of Traditional and Contingency Theory Postulates", Journal of Marketing 60 (April):105-120.

[30] Robbins, Stephen P. (2003), Essentials of Organizational behavior", eighth edition, prentice hall.

[31] Robert N. Anthony and Vijay Govindarajan (2005), Management Control System, Mc Graw Hill

[32] Richard Popple (2009), Claims and The Credit Crunch : A Crawford \& Company UK White paper, London

[33] Senge, P. et. al. (1994) The Fifth Discipline Field book: Strategies and Tools for Building a Learning Organization

[34] Sekaran, U. (1999), Research Methods for Business: A Skill Building Approach. $2^{\text {th }}$, John Wiley \& Sons, Ltd

[35] Taylor Susan (2001), Reflection on Fairness: Continuing the Progression of Justice, Maryland University

[36] Tekleab (2004), Extending The Chain Of Relationships Among Organizational Justice, Social Exchange, And Employee Reactions: The Role Of Contract Violations

[37] Thomas Rude (2000), "Evidence Seizure Methodology for Computer Forensics", CISSP

[38] Williamson Oliver (2007), Transactional Cost Theory An Introduction, Discccion Pape, California Barkeley

[39] Wolfe, D., and D. R. Hermanson. 2004. The fraud diamond: Considering four elements of fraud. The CPA Journal (December): 38-42

\section{The Indonesian Regulation}

a. Republik Indonesia, (1998), Undang-Undang Nomor 10 Tahun 1998 tentang Perubahan Undang-Undang No. 7 Tahun 1992 tentang Perbankan. Jakarta.

b. Bank Indonesia. (2003). "Surat Edaran Bank Indonesia No 5/22/DPNP, tanggal 29 September 2003, Perihal Pedoman Standar Sistem Pengendalian Intern bagi Bank Umum". Jakarta. Indonesia.

c. Bank Indonesia. (2003). "Peraturan Bank Indonesia No 5/8/PBI/2003, tanggal 19 Mei 2003, Perihal Penerapan Manajemen Risiko bagi Bank Umum". Jakarta. Indonesia.

d. Bank Indonesia. (2006). "Peraturan Bank Indonesia No 8/4/PBI/2006, tanggal 30 Januari 2006, Perihal Pelaksanaan Good Corporate Governance bagi Bank Umum". Jakarta. Indonesia.

e. Bank Indonesia (1998), "Keputusan Direksi No.31 / 147 / Kep / DIR Tanggal 12 November 1998 tentang kualitas aktiva produktif pasal 6 ayat 1 . Jakarta. Indonesia 